\title{
Hepatitis E Virus Methyltransferase Inhibits Type I Interferon Induction by Targeting RIG-I
}

\author{
Sangmin Kang ${ }^{1}$, Changsun Choi ${ }^{2}$, Insoo Choi ${ }^{3}$, Kwi-Nam Han ${ }^{4}$, Seong Woon Roh ${ }^{5}$, Jongsun Choi ${ }^{4}$, Joseph Kwon ${ }^{4}$, \\ Mi-Kyung Park ${ }^{6}$, Seong-Jun $\mathrm{Kim}^{7}$, and Jinjong Myoung ${ }^{1 *}$ \\ ${ }^{1}$ Korea Zoonosis Research Institute and Genetic Engineering Research Institute, Chonbuk National University, Jeonju 54896, Republic of Korea \\ ${ }^{2}$ Department of Food and Nutrition, Chung-Ang University, Anseong 17546, Republic of Korea \\ ${ }^{3}$ Department of Infectious Disease, College of Veterinary Medicine, Konkuk University, Seoul 05029, Republic of Korea \\ ${ }^{4}$ Biological Disaster Analysis Group, Korea Basic Science Research Institute, Daejeon 34133, Republic of Korea \\ ${ }^{5}$ World Institute of Kimchi, Gwangju 61755, Republic of Korea \\ ${ }^{6}$ Food and Bio-industry Research Institute, Kyungpook National University, Daegu 41566, Republic of Korea \\ ${ }^{7}$ Center for Convergent Research of Emerging Virus Infection, Korea Research Institute of Chemical Technology, Daejeon 34114, Republic of Korea
}

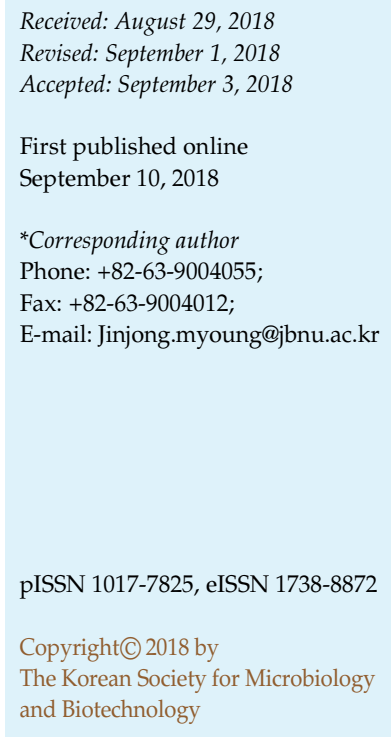

The type I interferons (IFNs) play a vital role in activation of innate immunity in response to viral infection. Accordingly, viruses have evolved to employ various survival strategies to evade innate immune responses induced by type I IFNs. For example, hepatitis E virus (HEV) encoded papain-like cysteine protease (PCP) has been shown to inhibit IFN activation signaling by suppressing K63-linked de-ubiquitination of retinoic acid-inducible gene I (RIG-I) and TANK-binding kinase 1 (TBK1), thus effectively inhibiting down-stream activation of IFN signaling. In the present study, we demonstrated that HEV inhibits polyinosinic-polycytidylic acid (poly(I:C))-induced IFN- $\beta$ transcriptional induction. Moreover, by using reporter assay with individual HEV-encoded gene, we showed that HEV methyltransferase (MeT), a nonstructural protein, significantly decreases RIG-I-induced IFN- $\beta$ induction and NF- $\kappa$ B signaling activities in a dose-dependent manner. Taken together, we report here that MeT, along with PCP, is responsible for the inhibition of RIG-I-induced activation of type I IFNs, expanding the list of HEV-encoded antagonists of the host innate immunity.

Keywords: Hepatitis E virus, methyltransferase, RIG-I

\section{Introduction}

Hepatitis E virus (HEV) is one of hepatitis viruses that cause liver disease [1]. Annually, roughly 20 million people are infected with HEV worldwide according to The World Health Organization (WHO). Hepatitis E virus transmission is known to be prevalent in developing countries [2-4], but in recent years, it has also been detected in industrialized countries such as UK, France, and Germany [5]. HEV infection is mostly asymptomatic or a self-limiting acute illness, rarely progressing to persistent infection. However, its infection in pregnant women can cause high mortality rate up to $20 \sim 30 \%[6,7]$. The HEV variants are classified into 7 genotypes (GT1-7), among which four major genotypes are associated with human infection. GT1 and GT2 HEV are restricted to human infection, whereas GT3 and GT4 HEV are zoonotic, infecting both human and animals such as domestic pig, deer, and wild boar [2, 8, 9].

$\mathrm{HEV}$ is a non-enveloped virus with a single-stranded, positive-sense RNA genome, which is approximately $7.2 \mathrm{~kb}$ in length. Its genome consists of the $5^{\prime}$ untranslated region (UTR), three overlapping open reading frames (ORF1, ORF2, ORF3) and the 3' UTR followed by poly A [10-12]. The ORF1 encodes 7 non-structural replication proteins: methyltransferase, Y-domain, papain-like cysteine protease (PCP), hypervariable region (HVR), X-domain, RNA helicase, and RNA-dependent RNA polymerase (RdRp), all of which are involved in the viral genome replication and 
polyprotein processing [13-15]. ORF2 encodes the viral capsid protein that plays important functions in virus infection and virion assembly [16-18]. ORF3 encodes a small phosphoprotein of 113 or 114 amino acids that is essential for virus egress from infected cells [19-21]. Recently, Nair et al. showed that ORF4 is expressed only under endoplasmic reticulum (ER) stress and interacts with multiple viral proteins, stimulating activity of viral RdRp [22].

Type I Interferon (IFN) is the first line defense against viral infection, stimulating a series of subsequent anti-viral immune responses [23-26]. Recent studies suggest that type I IFNs are also involved in the pathogenesis of chronic inflammatory disease as well as in anti-cancer immunity $[25,27]$. Upon virus infection into the cells, pathogen recognition receptors (PRRs), such as retinoic-acid-inducible gene I (RIG-I), melanoma differentiation-associated protein 5 (MDA5) and Toll-like receptors (TLRs), recognize the viral genome [28-30] and rapidly activate type I IFN production through a cascade of downstream signaling molecules, such as mitochondrial antiviral-signaling protein (MAVS) [31-33], TIR-domain-containing adapter-inducing interferon- $\beta$ (TRIF) [34, 35], I kappa B kinase epsilon (IKKE)/TANK-binding kinase 1 (TBK1) [36-40], interferon regulatory factor 3 (IRF3) [41-43], IRF7 [44], and nuclear factor kappa-light-chain-enhancer of activated B cells (NF-кB) $[33,45,46]$. Activation of those factors leads to expression of IFN- $\alpha / \beta$ and interferon-stimulated genes (ISGs) that induce efficient antiviral immune responses in an endocrine and paracrine manner [47, 48]. Interestingly enough, pathogenic viruses have evolved a slew of immune escape strategies to avoid and/or disrupt the host immune system $[49,50]$. For example, hepatitis $C$ virus (HCV) encodes viral proteins, such as core, E2, NS3/4A, and NS5A, which have been shown to be involved in innate immune evasion by directly or indirectly regulating the type I IFN production signaling cascade [51], thus contributing to the establishment of chronic viral infection [52-58].

On the contrary, little is known on the HEV-encoded mechanisms of type I IFN evasion [59]. Treatment of recombinant IFN- $\alpha$ on HEV replicon-harboring cells revealed that HEV replication was partially inhibited. These results imply for HEV-encoded antagonist(s) of IFN- $\alpha$-induced antiviral immune response [60, 61]. For example, HEV PCP protein seems to suppress K63-linked de-ubiquitination of RIG-I and TBK1, which is essential for their activation and IFN- $\beta$ expression [62-64]. However, detailed mechanisms of PCP-mediated evasion strategy against type I IFN response have not been delineated yet. Moreover, it is still likely that HEV-encoded proteins, other than $\mathrm{PCP}$, may also be involved in antagonizing the type I IFN response. Therefore, we aimed to screen each and every HEV protein for their inhibitory activities on type I IFN signaling molecules. Here, we demonstrate that besides PCP, HEV methyltransferase (MeT) is a strong antagonist of the type I IFN by inhibiting RIG-I-mediated activation. Furthermore, RIG-I-mediated activation of NF- $\mathrm{KB}$ is also inhibited by HEV MeT. Taken together, these results establish a novel function of HEV MeT in the inhibition of and thus the immune evasion of type I IFNs.

\section{Materials and Methods}

\section{Annotation of HEV Genomes}

A set of 3 different viral genome sequences were obtained from Genbank. The genes for each viral protein were annotated with significant similarity in amino acid sequences based on a genotype 3 HEV (47832c; Genbank: KC618403), compared with genotype $1 \mathrm{HEV}$ L08816 and AF082843, which were isolated from swine.

\section{Cells and Reagents}

HEK293T cells were grown and maintained in Dulbecco's Modified Eagle Medium (DMEM, Gibco, USA) supplemented with 10\% fetal bovine serum (Gibco, USA) and 1\% streptomycin (Gibco, USA) in a humidifying incubator at $37^{\circ} \mathrm{C}$ with $5 \% \mathrm{CO}_{2}$ [65-69]. A549/D3 and A549/HEV cells [70] were maintained in DMEM supplemented with $5 \%$ calf bovine serum and $1 \%$ streptomycin in a humidifying incubator at $37^{\circ} \mathrm{C}$ with $5 \% \mathrm{CO}_{2}$. Detailed procedures for cell culture were described elsewhere [71-77]. For transfection, polyethylenimmine (PEI) solution was prepared (Sigma-Aldrich) and DNA:PEI ratio was 1:2 to form DNA-transfection reagent complex [78-81]. High molecular weight polyinosinic-polycytidylic acid (poly(I:C)) was purchased from Invivogen [82].

\section{Plasmid Construction and Western Blotting}

cDNA corresponding to the individual gene of HEV (GT3, 47832c) was generated by reverse transcriptase (MMLV, Thermo Fischer Scientific) followed by PCR using specific primers. Resulting cDNA was cloned into p3xFLAG-CMV-10 (SigmaAldrich). Plasmid encoding each HEV gene was transfected into HEK293T cells and assessed for its expression by anti-FLAG antibody (M2, Sigma-Aldrich). Detailed procedures were described elsewhere [83-87].

\section{Luciferase Reporter Assay}

HEK293T cells were seeded in a 6-well plate the day before transfection and then transfected for $24 \mathrm{~h}$ with various plasmids, as indicated in the figures. The cells were lysed using reporter lysis $5 \times$ buffer (Promega, USA). Luciferase activity in the cell 
lysates was determined using luciferase assay system (Promega, USA), and the luminescence was measured by the Glomax (Promega, USA) according to the manufacturer's instructions. Luminescence of firefly luciferase was normalized by betagalactosidase activity.

\section{Statistical Analysis}

Data are shown as one representative example from at least two independent experiments. The statistical significance was determined by the Student's $t$ test. $P<0.05$ was considered statistically significant.

\section{Results}

\section{HEV Inhibits IFN- $\beta$ Transcriptional Activation Induced by $\operatorname{Poly}(\mathrm{I}: \mathrm{C})$}

A549/D3 cell line was subcloned from A549 cells for its high susceptibility to HEV [88], which was also shown to support HEV replication and virus production at high levels. Interestingly, HEV infection was stably maintained over time, resulting in the generation of an HEV stable cell line, A549/HEV [88], which was utilized in this study for investigating the mechanism(s) of HEV-mediated disruption

A

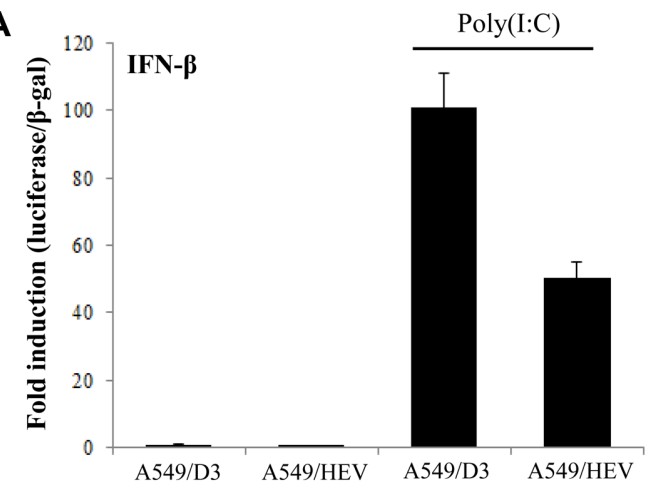

B

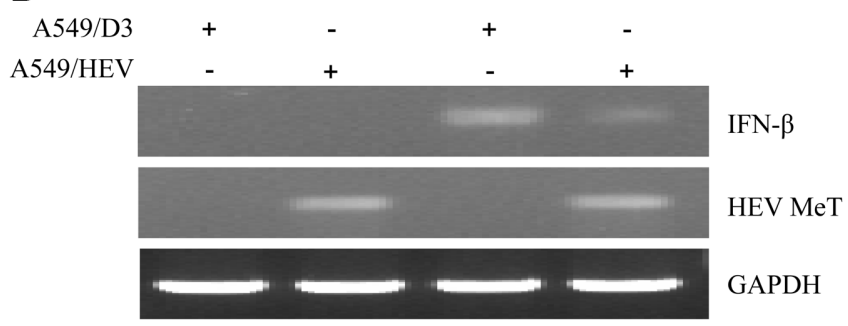

Fig. 1. Poly(I:C)-induced IFN- $\beta$ reporter activities decreased in HEV infected cells.

A549/D3 and A549/HEV cells were seeded at $1 \times 10^{6}$ in a 6-well plate. After $24 \mathrm{~h}$, cells were treated with $1 \mu \mathrm{g} / \mathrm{ml}$ of poly(I:C) for $12 \mathrm{~h}$. Cells were subsequently subjected to either IFN- $\beta$ reporter assay (A) or RT-PCR (B). of type I IFN signaling. Previously, poly(I:C)-treated A549 cells expressed type I IFN proteins at increasing levels in a time-dependent manner (12-72 h) [89]. As IFN- $\beta$ is a key factor for innate immune response and is a major target of viral evasion [46, 90], we sought to test whether HEV modulates poly(I:C)-mediated induction of type I IFN expression in A549/D3 and A549/HEV cells. Two cell lines were co-transfected with IFN- $\beta$-luciferase (IFN- $\beta$-luc) reporter and beta-galactosidase ( $\beta$-gal) plasmid, and treated with $1 \mu \mathrm{g} / \mathrm{ml}$ poly(I:C) for $12 \mathrm{~h}$. Poly(I:C)-mediated induction of IFN- $\beta$ reporter activity (Fig. 1A) and expression of IFN- $\beta$ mRNA (Fig. 1B) were significantly inhibited in the context of HEV infection. These results strongly suggest for the presence of HEV-encoded antagonistic mechanisms against type I IFN signaling.

\section{HEV MeT and PCP Protein Inhibits Poly(I:C)-Induced IFN- $\beta$ Production}

With an aim to screen out HEV protein(s) that inhibit type I IFN signaling, we first annotated each HEV gene encoded in the genome of HEV 47832c strain (GT3) as shown in Fig. 2A. ORF1 is translated into a polypeptide, which is proteolytically cleaved to 7 nonstructural replication proteins. Each nonstructural gene as well as ORF2 and ORF3 was cloned into the plasmid, p3xFLAG-CMV10, and its protein expression was analyzed by Western blotting (Fig. 2B). To examine which viral protein(s) are responsible for the inhibition of IFN signaling, HEK293T cells were cotransfected with IFN- $\beta$-luc reporter and $\beta$-gal plasmids, and each viral gene-expressing plasmid. At $24 \mathrm{~h}$ posttransfection, cells were stimulated with $5 \mu \mathrm{g} / \mathrm{ml}$ poly(I:C) for $8 \mathrm{~h}$ to activate RIG-I-like receptor (RLR)-mediated IFN signaling. Poly(I:C)-induced IFN- $\beta$ reporter activity was roughly $30 \%$ suppressed by the expression of MeT (Fig. 3), suggesting that MeT plays a role in antagonizing RLRmediated activation of innate immune responses. As expected, HEV-encoded PCP significantly reduced poly(I:C)mediated induction of IFN- $\beta$ promoter activation (Fig. 3). Therefore, it seems that our result recapitulated previous findings while providing new insights as well.

To investigate whether MeT-mediated inhibition was RIG-I-mediated, HEK293T cells were co-transfected with IFN- $\beta$-luc, $\beta$-gal and RIG-I-expressing plasmids together with an increasing amount of HEV MeT-expressing plasmid. Interestingly, MeT inhibited RIG-I-mediated activation of IFN- $\beta$ signaling in a dose-dependent manner (Fig. 4A, top panel). Of note, RIG-I protein levels were not changed even when increasing levels of $\mathrm{MeT}$ protein were present (Fig. 4A, bottom panel). 
A

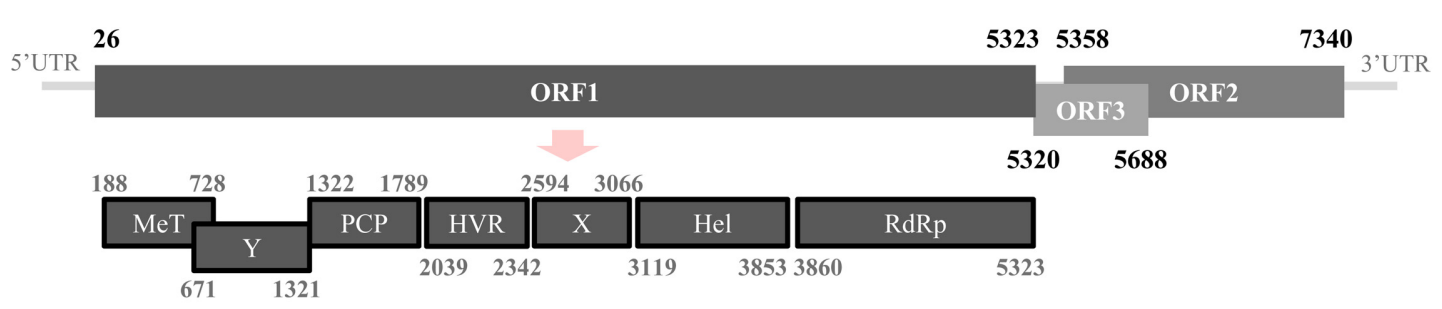

B

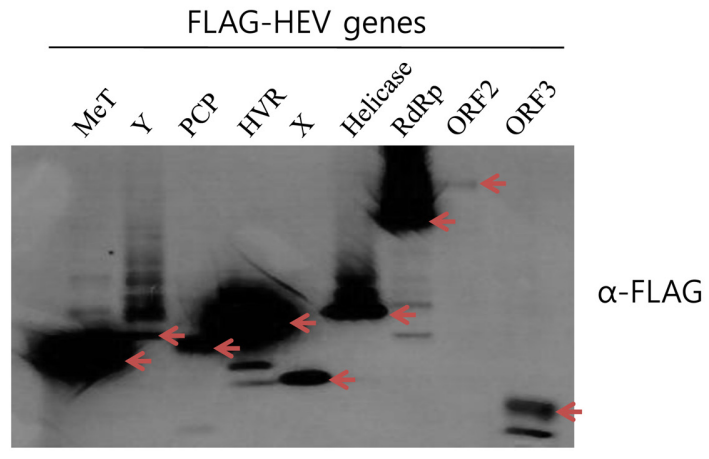

Fig. 2. Annotation of HEV-encoded genes and expression of them in fusion to FLAG tag at the N-terminus.

(A) Schematic diagram of viral proteins encoded in the HEV genome. ORF1 encodes seven nonstructural proteins, methyltransferase, Y, papainlike cysteine protease, hypervariable region (HVR), X, RNA helicase, and RNA-dependent RNA polymerase. (B) Each of viral genes was cloned into a Flag-tag vector and transfected into HEK293T cells. Cell extracts $(20 \mu \mathrm{g})$ were loaded onto a SDS-PAGE gel and analyzed by immunoblot with anti-FLAG antibody (M2).

\section{MeT Inhibits RIG-I-Mediated NF- $\kappa$ B Activation}

For a full activation of IFN- $\beta$ promoter activity, adequate $\mathrm{NF}-\kappa \mathrm{B}$ activation is prerequisite. To investigate if $\mathrm{HEV} \mathrm{MeT}$ downregulates RIG-I-mediated activation of NF-кB, HEK293T cells were co-transfected with NF-кB-luc, $\beta$-gal, and RIG-I expressing plasmids together with an increasing amount of HEV MeT-expressing plasmid. When $1 \mu \mathrm{g}$ of FLAG-tagged MeT-expressing plasmid was transfected, NF- $\mathrm{B}$ activity was around $40 \%$ inhibited. And the inhibitory activity was left unchanged in the presence of higher levels of MeT expression, suggesting that RIG-I-mediated signalinginduced activation of NF- $\kappa$ B is inhibited by $\mathrm{MeT}$ in a dosedependent manner. However, as seen in IFN- $\beta$ reporter assay (Fig. 4A, bottom panel), RIG-I protein levels were not perturbed (Fig. 4B, bottom panel).

\section{Discussion}

Upon viral infection, the first line defense activated in the host cell is type I IFNs. MDA5 and RIG-I are sensors of viral mRNA. Both molecules recognize the RNA genome of invading pathogens, previous reports have shown that RIG-I and MDA5 have similar functions. However, the type and magnitude of their activation depends on the nature of their cognate ligands and stimuli [91, 92]. The nature and structure of the RNA molecules recognized by RLR's is known to vary. RIG-I binds to relatively short 5' triphosphate RNA, and the RNA should be blunted. However, MDA5 does not have those restrictions and can bind to relatively long RNA's. Upon recognition, these molecules induce and activate MAVS on the mitochondrial outer membrane. MAVS, in turn, activates TBK1 and IKK $\varepsilon$, phosphorylating IRF3. Phosphorylated IRF3 dimerizes with itself or phosphorylates IRF7, translocating into the nucleus and consequently transcribing IFN- $\beta$ mRNA. Therefore, it is of paramount importance to analyze which molecule of the two (MDA5 or RIG-I) recognizes HEV genome and how HEV counteracts the IFN-mediated innate immunity.

When HEV-infected or naïve A549/D3 cells were transfected with poly(I:C), which activates IFN- $\beta$ expression mainly through RIG-I-Like receptors, poly(I:C)-mediated activation 


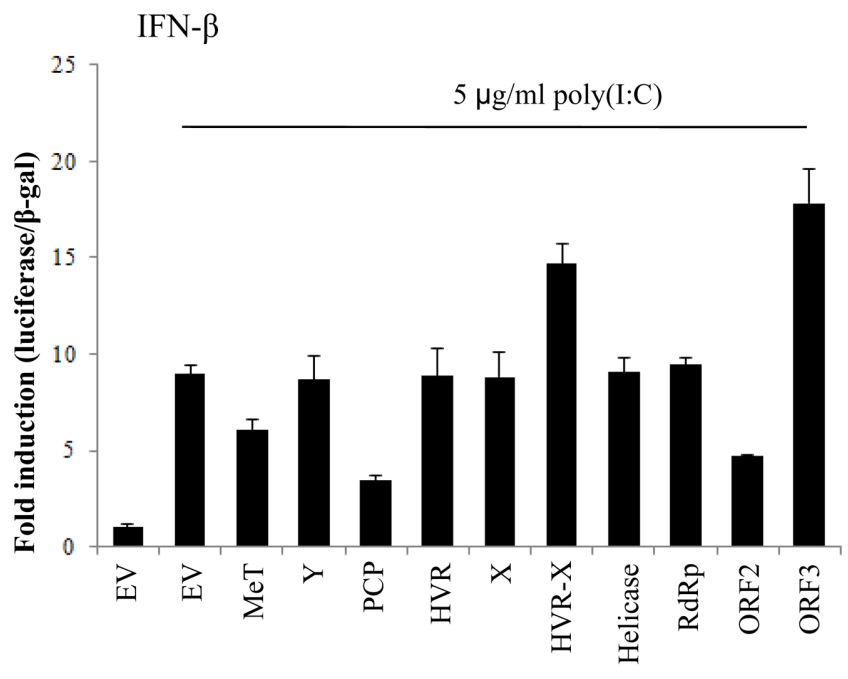

HEV-encoded genes

Fig. 3. HEV MeT, PCP, and ORF2 inhibits poly(I:C)-induced IFN- $\beta$ induction.

Plasmids encoding HEV genes were transfected with IFN- $\beta$-luc and $\beta$-gal plasmids into HEK293T cells. At $24 \mathrm{~h}$ post-transfection, cells were treated with poly(I:C) at $5 \mu \mathrm{g} / \mathrm{ml}$ for $8 \mathrm{~h}$ and the luciferase activity was then measured. EV; empty vector, MeT; methyltransferase, PCP; papain-like cysteine protease, HVR; hypervariable region, RdRp; RNA-dependent RNA polymerase.

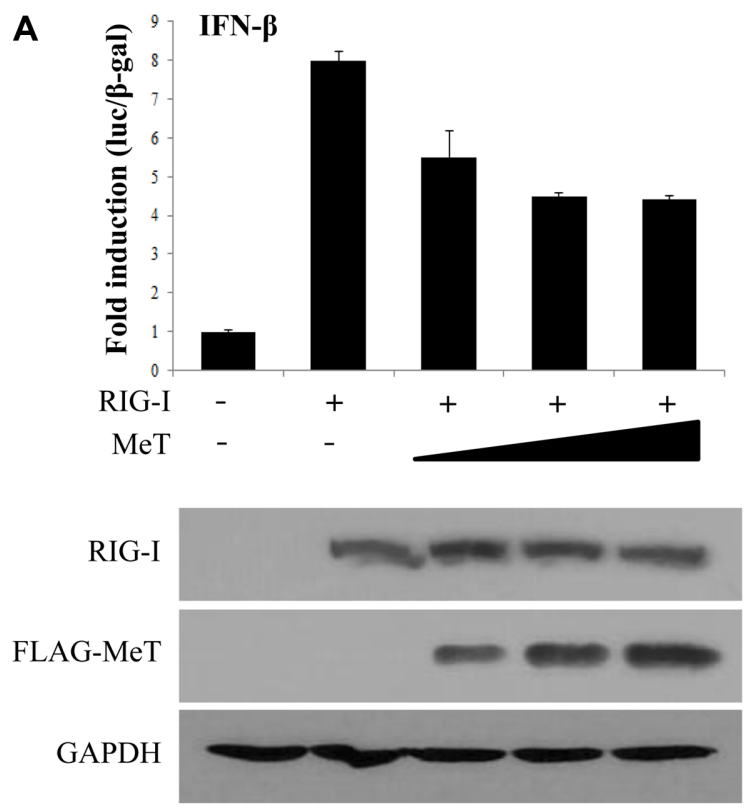

of IFN- $\beta$ promoter activity was over $60 \%$ suppressed in the context of HEV infection (Fig. 1A). Reduction in luciferase activity was well-correlated with significant decrease in mRNA levels of IFN- $\beta$ (Fig. 1B). These data strongly suggest that HEV may encode viral mechanism(s) that inhibit RLRmediated activation of IFN- $\beta$. It turns out that HEV-encoded $\mathrm{MeT}, \mathrm{PCP}$ and ORF2 are responsible for the inhibition of HEV (Fig. 3). As PCP has been shown to inhibit RIG-Imediated IFN signaling, subsequent studies focused on the role of $\mathrm{MeT}$ in the RIG-I-mediated activation of IFN signaling. Of note, MeT inhibited RIG-I-mediated IFN- $\beta$ induction in a dose-dependent manner (Fig. 4A, top panel), suggesting that MeT may directly or indirectly target RIG-I. Further studies are warranted to investigate molecular mechanisms that underlie MeT-mediated inhibition of RIGI. It is interesting to note that protein levels of RIG-I are not perturbed even in the presence of increasing amounts of MeT (Fig. 4A, bottom panel), suggesting that MeT may regulate RIG-I-mediated signaling at the post-translational level. Currently, studies are underway to fathom its molecular mechanisms. It is well established that the activation of $\mathrm{NF}-\kappa \mathrm{B}$ is required for full activation of IFN- $\beta$ signaling. Therefore, it is important to analyze if RIG-I-mediated activation of NF- $\mathrm{kB}$ is also regulated by the expression of MeT. Interestingly, MeT significantly inhibited RIG-I-

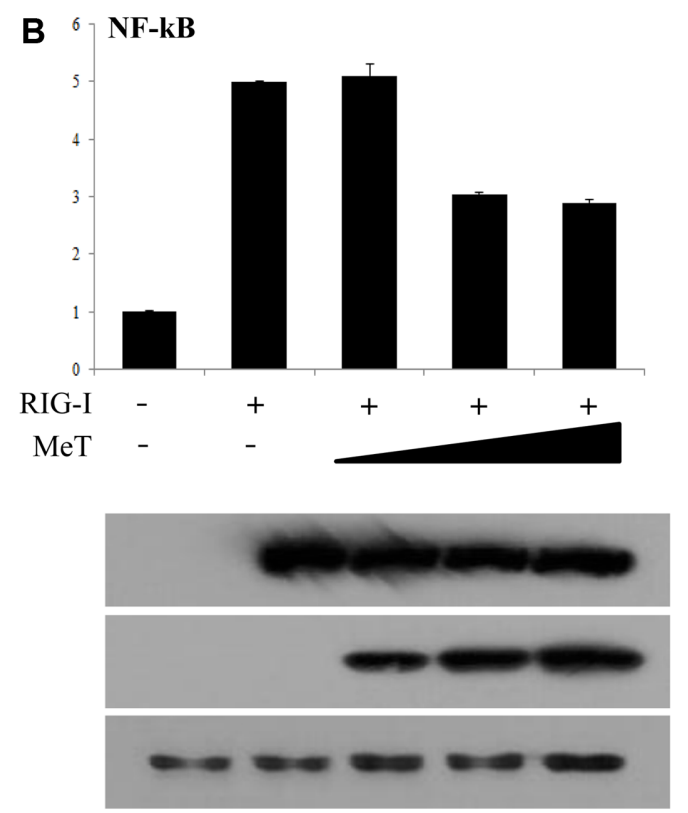

Fig. 4. HEV MeT inhibits RIG-I-induced IFN- $\beta$ and NF-kB induction.

HEK293T cells were transfected for $24 \mathrm{~h}$ with IFN- $\beta$ (A) or NF-kB reporter (B) construct, $\beta$-gal, and RIG-I expression plasmids as well as with increasing amounts $(0.5,1$, and $2 \mu \mathrm{g})$ of FLAG-tagged MeT expression plasmid before subjected to luciferase assay. Shown above are the data from three independent experiments. 
mediated activation of NF- $\kappa \mathrm{B}$ activities in a dose-independent manner (Fig. 4B). Taken together, these data suggest that MeT inhibits both RIG-I-mediated signaling and NF-кB activity, leading to attenuation of IFN- $\beta$ production. Therefore, MeT can be added to the list of HEV-encoded antagonists of IFN- $\beta$ signaling that can help effectively counteract and thus develop strong therapeutic strategies for HEV infection.

\section{Acknowledgment}

A549/D3 and A549/HEV cells were kindly provided by Dr. Reimar Johne. We thank Dr. Soon Bong Hwang for his generous gifts of plasmids encoding MDA5 and RIG-I. This research was supported by Basic Science Research Program through the National Research Foundation (NRF) funded by the Ministry of Education (2017R1A6A1A03015876) and by a grant from the Center for Analytical Research of Disaster Science of Korea Basic Science Institute (C38711) to J. Kwon.

\section{Conflict of Interest}

The authors have no financial conflicts of interest to declare.

\section{References}

1. Aggarwal R, Naik S. 2009. Epidemiology of hepatitis E: current status. J. Gastroenterol. Hepatol. 24: 1484-1493.

2. Arankalle VA, Chobe LP, Chadha MS. 2006. Type-IV Indian swine HEV infects rhesus monkeys. J. Viral Hepat. 13: 742745.

3. Teshale EH, Hu DJ, Holmberg SD. 2010. The two faces of hepatitis E virus. Clin. Infect. Dis. 51: 328-334.

4. Naik SR, Aggarwal R, Salunke PN, Mehrotra NN. 1992. A large waterborne viral hepatitis E epidemic in Kanpur, India. Bull. World Health Organ. 70: 597-604.

5. Ricci A, Allende A, Bolton D, Chemaly M, Davies R, Escamez PSF, et al. 2017. Public health risks associated with hepatitis E virus (HEV) as a food-borne pathogen. EFSA J. 15.

6. Jilani N, Das BC, Husain SA, Baweja UK, Chattopadhya D, Gupta RK, et al. 2007. Hepatitis E virus infection and fulminant hepatic failure during pregnancy. J. Gastroenterol. Hepatol. 22: 676-682.

7. Navaneethan U, Al Mohajer M, Shata MT. 2008. Hepatitis E and pregnancy: understanding the pathogenesis. Liver Int. 28: 1190-1199.

8. Pavio N, Meng XJ, Doceul V. 2015. Zoonotic origin of hepatitis E. Curr. Opin. Virol. 10: 34-41.

9. Meng XJ. 2010. Hepatitis E virus: animal reservoirs and zoonotic risk. Vet. Microbiol. 140: 256-265.

10. Tam AW, Smith MM, Guerra ME, Huang CC, Bradley DW, Fry KE, et al. 1991. Hepatitis E virus (HEV): molecular cloning and sequencing of the full-length viral genome. Virology 185: 120-131.

11. Koonin EV, Gorbalenya AE, Purdy MA, Rozanov MN, Reyes GR, Bradley DW. 1992. Computer-assisted assignment of functional domains in the nonstructural polyprotein of hepatitis E virus: delineation of an additional group of positive-strand RNA plant and animal viruses. Proc. Natl. Acad. Sci. USA 89: 8259-8263.

12. Graff J, Torian U, Nguyen H, Emerson SU. 2006. A bicistronic subgenomic mRNA encodes both the ORF2 and ORF3 proteins of hepatitis E virus. J. Virol. 80: 5919-5926.

13. Ropp SL, Tam AW, Beames B, Purdy M, Frey TK. 2000. Expression of the hepatitis E virus ORF1. Arch. Virol. 145: 1321-1337.

14. Sehgal D, Thomas S, Chakraborty M, Jameel S. 2006. Expression and processing of the Hepatitis E virus ORF1 nonstructural polyprotein. Virol. J. 3: 38.

15. Suppiah S, Zhou Y, Frey TK. 2011. Lack of processing of the expressed ORF1 gene product of hepatitis E virus. Virol. J. 8: 245.

16. Graff J, Zhou YH, Torian U, Nguyen H, St Claire M, Yu C, et al. 2008. Mutations within potential glycosylation sites in the capsid protein of hepatitis E virus prevent the formation of infectious virus particles. J. Virol. 82: 1185-1194.

17. Shiota T, Li TC, Yoshizaki S, Kato T, Wakita T, Ishii K. 2013. The hepatitis $\mathrm{E}$ virus capsid C-terminal region is essential for the viral life cycle: implication for viral genome encapsidation and particle stabilization. J. Virol. 87: 6031-6036.

18. Qi Y, Zhang F, Zhang L, Harrison TJ, Huang W, Zhao C, et al. 2015. Hepatitis E virus produced from cell culture has a lipid envelope. PLoS One 10: e0132503.

19. Yamada K, Takahashi M, Hoshino Y, Takahashi H, Ichiyama K, Nagashima S, et al. 2009. ORF3 protein of hepatitis $\mathrm{E}$ virus is essential for virion release from infected cells. J. Gen. Virol. 90: 1880-1891.

20. Nagashima S, Takahashi M, Jirintai, Tanaka T, Yamada $K$, Nishizawa T, et al. 2011. A PSAP motif in the ORF3 protein of hepatitis E virus is necessary for virion release from infected cells. J. Gen. Virol. 92: 269-278.

21. Kenney SP, Pudupakam RS, Huang YW, Pierson FW, LeRoith T, Meng XJ. 2012. The PSAP motif within the ORF3 protein of an avian strain of the hepatitis $E$ virus is not critical for viral infectivity in vivo but plays a role in virus release. J. Virol. 86: 5637-5646.

22. Nair VP, Anang S, Subramani C, Madhvi A, Bakshi K, Srivastava A, et al. 2016. Endoplasmic reticulum stress induced synthesis of a novel viral factor mediates efficient replication of genotype-1 hepatitis E virus. PLoS Pathog. 12: e1005521.

23. Theofilopoulos AN, Baccala R, Beutler B, Kono DH. 2005. 
Type I interferons (alpha/beta) in immunity and autoimmunity. Annu. Rev. Immunol. 23: 307-336.

24. Xi Y, Day SL, Jackson RJ, Ranasinghe C. 2012. Role of novel type I interferon epsilon in viral infection and mucosal immunity. Mucosal. Immunol. 5: 610-622.

25. Zitvogel L, Galluzzi L, Kepp O, Smyth MJ, Kroemer G. 2015. Type I interferons in anticancer immunity. Nat. Rev. Immunol. 15: 405-414.

26. Kang S, Myoung J. 2017. Primary lymphocyte infection models for KSHV and its putative tumorigenesis mechanisms in B cell lymphomas. J. Microbiol. 55: 319-329.

27. Yarilina A, Ivashkiv LB. 2010. Type I interferon: a new player in TNF signaling. Curr. Dir. Autoimmun. 11: 94-104.

28. Akira S, Uematsu S, Takeuchi O. 2006. Pathogen recognition and innate immunity. Cell 124: 783-801.

29. Medzhitov R. 2007. Recognition of microorganisms and activation of the immune response. Nature 449: 819-826.

30. Fujita T, Onoguchi K, Onomoto K, Hirai R, Yoneyama M. 2007. Triggering antiviral response by RIG-I-related RNA helicases. Biochimie 89: 754-760.

31. Kawai T, Takahashi K, Sato S, Coban C, Kumar H, Kato H, et al. 2005. IPS-1, an adaptor triggering RIG-I- and Mda5mediated type I interferon induction. Nat. Immunol. 6: 981-988.

32. Meylan E, Curran J, Hofmann K, Moradpour D, Binder M, Bartenschlager $\mathrm{R}$, et al. 2005. Cardif is an adaptor protein in the RIG-I antiviral pathway and is targeted by hepatitis C virus. Nature 437: 1167-1172.

33. Seth RB, Sun L, Ea CK, Chen ZJ. 2005. Identification and characterization of MAVS, a mitochondrial antiviral signaling protein that activates NF-kappaB and IRF 3. Cell 122: 669-682.

34. Hardy MP, Mc GAF, O'Neill LA. 2004. Transcriptional regulation of the human TRIF (TIR domain-containing adaptor protein inducing interferon beta) gene. Biochem. J. 380: 83-93.

35. Yamamoto $M$, Sato $S$, Hemmi $H$, Hoshino $K$, Kaisho $T$, Sanjo $\mathrm{H}$, et al. 2003. Role of adaptor TRIF in the MyD88independent toll-like receptor signaling pathway. Science 301: 640-643.

36. Fitzgerald KA, McWhirter SM, Faia KL, Rowe DC, Latz E, Golenbock DT, et al. 2003. IKKepsilon and TBK1 are essential components of the IRF3 signaling pathway. Nat. Immunol. 4: 491-496.

37. Chau TL, Gioia R, Gatot JS, Patrascu F, Carpentier I, Chapelle JP, et al. 2008. Are the IKKs and IKK-related kinases TBK1 and IKK-epsilon similarly activated? Trends Biochem. Sci. 33: 171-180.

38. Hacker H, Karin M. 2006. Regulation and function of IKK and IKK-related kinases. Sci. STKE 2006: re13.

39. Gatot JS, Gioia R, Chau TL, Patrascu F, Warnier M, Close P, et al. 2007. Lipopolysaccharide-mediated interferon regulatory factor activation involves TBK1-IKKepsilon-dependent Lys(63)linked polyubiquitination and phosphorylation of TANK/ITRAF. J. Biol. Chem. 282: 31131-31146.

40. Clement JF, Meloche S, Servant MJ. 2008. The IKK-related kinases: from innate immunity to oncogenesis. Cell Res. 18: 889-899.

41. Grandvaux N, Servant MJ, tenOever B, Sen GC, Balachandran S, Barber GN, et al. 2002. Transcriptional profiling of interferon regulatory factor 3 target genes: direct involvement in the regulation of interferon-stimulated genes. J. Virol. 76: 5532-5539.

42. Honda K, Taniguchi T. 2006. IRFs: master regulators of signalling by Toll-like receptors and cytosolic patternrecognition receptors. Nat. Rev. Immunol. 6: 644-658.

43. Liu S, Cai X, Wu J, Cong Q, Chen X, Li T, et al. 2015. Phosphorylation of innate immune adaptor proteins MAVS, STING, and TRIF induces IRF3 activation. Science 347: aaa2630.

44. Honda K, Yanai H, Negishi H, Asagiri M, Sato M, Mizutani T, et al. 2005. IRF-7 is the master regulator of type-I interferondependent immune responses. Nature 434: 772-777.

45. Hiscott J, Grandvaux N, Sharma S, Tenoever BR, Servant MJ, Lin R. 2003. Convergence of the NF-kappaB and interferon signaling pathways in the regulation of antiviral defense and apoptosis. Ann. NY Acad. Sci. 1010: 237-248.

46. Wang J, Basagoudanavar SH, Wang X, Hopewell E, Albrecht R, Garcia-Sastre A, et al. 2010. NF-kappa B RelA subunit is crucial for early IFN-beta expression and resistance to RNA virus replication. J. Immunol. 185: 1720-1729.

47. Song JW, Guan M, Zhao ZW, Zhang JJ. 2015. Type I interferons function as autocrine and paracrine factors to induce autotaxin in response to TLR activation. PLoS One $\mathbf{1 0 .}$

48. Hu J, Lou DH, Carow B, Winerdal ME, Rottenberg M, Wikstrom AC, et al. 2012. LPS Regulates SOCS2 transcription in a type I interferon dependent autocrine-paracrine loop. PLoS One 7.

49. Draenert R, Frater J, Prado JG. 2012. Virus immune evasion: new mechanism and implications in disease outcome. Adv. Virol. 2012: 490549.

50. Senba M, Mori N. 2012. Mechanisms of virus immune evasion lead to development from chronic inflammation to cancer formation associated with human papillomavirus infection. Oncol. Rev. 6: e17.

51. Wi J, Jeong MS, Hong HJ. 2017. Construction and Characterization of an anti-hepatitis B virus preS1 humanized antibody that binds to the essential receptor binding site. J. Microbiol. Biotechnol. 27: 1336-1344.

52. Bode JG, Ludwig S, Ehrhardt C, Albrecht U, Erhardt A, Schaper F, et al. 2003. IFN-alpha antagonistic activity of HCV core protein involves induction of suppressor of cytokine signaling-3. FASEB J. 17: 488-490.

53. Lin W, Kim SS, Yeung E, Kamegaya Y, Blackard JT, Kim KA, et al. 2006. Hepatitis $C$ virus core protein blocks interferon signaling by interaction with the STAT1 SH2 domain. J. Virol. 80: 9226-9235.

54. Taylor DR, Shi ST, Romano PR, Barber GN, Lai MM. 1999. Inhibition of the interferon-inducible protein kinase PKR by HCV E2 protein. Science 285: 107-110.

55. Li K, Foy E, Ferreon JC, Nakamura M, Ferreon AC, Ikeda M, 
et al. 2005. Immune evasion by hepatitis C virus NS3/4A protease-mediated cleavage of the Toll-like receptor 3 adaptor protein TRIF. Proc. Natl. Acad. Sci. USA 102: 2992-2997.

56. Li XD, Sun L, Seth RB, Pineda G, Chen ZJ. 2005. Hepatitis C virus protease NS3/4A cleaves mitochondrial antiviral signaling protein off the mitochondria to evade innate immunity. Proc. Natl. Acad. Sci. USA 102: 17717-17722.

57. Kang SM, Won SJ, Lee GH, Lim YS, Hwang SB. 2010. Modulation of interferon signaling by hepatitis $C$ virus nonstructural 5A protein: implication of genotypic difference in interferon treatment. FEBS Lett. 584: 4069-4076.

58. Lan KH, Lan KL, Lee WP, Sheu ML, Chen MY, Lee YL, et al. 2007. HCV NS5A inhibits interferon-alpha signaling through suppression of STAT1 phosphorylation in hepatocyte-derived cell lines. J. Hepatol. 46: 759-767.

59. Kang S, Myoung J. 2017. Host innate immunity against hepatitis E virus and viral evasion mechanisms. J. Microbiol. Biotechnol. 27: 1727-1735.

60. Zhou X, Xu L, Wang W, Watashi K, Wang Y, Sprengers D, et al. 2016. Disparity of basal and therapeutically activated interferon signalling in constraining hepatitis $\mathrm{E}$ virus infection. J. Viral. Hepat. 23: 294-304.

61. Krain LJ, Nelson KE, Labrique AB. 2014. Host immune status and response to hepatitis $\mathrm{E}$ virus infection. Clin. Microbiol. Rev. 27: 139-165.

62. Nan Y, Yu Y, Ma Z, Khattar SK, Fredericksen B, Zhang YJ. 2014. Hepatitis $E$ virus inhibits type I interferon induction by ORF1 products. J. Virol. 88: 11924-11932.

63. Karpe YA, Lole KS. 2011. Deubiquitination activity associated with hepatitis $\mathrm{E}$ virus putative papain-like cysteine protease. J. Gen. Virol. 92: 2088-2092.

64. Oshiumi H, Miyashita M, Matsumoto M, Seya T. 2013. A distinct role of Riplet-mediated K63-Linked polyubiquitination of the RIG-I repressor domain in human antiviral innate immune responses. PLoS Pathog. 9: e1003533.

65. Hamid FB, Kim J, Shin CG. 2017. Characterization of prototype foamy virus infectivity in transportin 3 knockdown human 293t cell line. J. Microbiol. Biotechnol. 27: 380-387.

66. Myoung J, Ganem D. 2011. Infection of lymphoblastoid cell lines by Kaposi's sarcoma-associated herpesvirus: critical role of cell-associated virus. J. Virol. 85: 9767-9777.

67. Myoung J, Ganem D. 2011. Generation of a doxycyclineinducible KSHV producer cell line of endothelial origin: maintenance of tight latency with efficient reactivation upon induction. J. Virol. Methods. 174: 12-21.

68. Myoung J, Ganem D. 2011. Infection of primary human tonsillar lymphoid cells by KSHV reveals frequent but abortive infection of T cells. Virology 413: 1-11.

69. Myoung J, Ganem D. 2011. Active lytic infection of human primary tonsillar B cells by KSHV and its noncytolytic control by activated CD4+ T cells. J. Clin. Invest. 121: 1130-1140.

70. Johne R, Trojnar E, Filter M, Hofmann J. 2016. Thermal stability of hepatitis $\mathrm{E}$ virus as estimated by a cell culture method. Appl. Environ. Microbiol. 82: 4225-4231.

71. Kang HS, Myoung J, So EY, Bahk YY, Kim BS. 2016. Transgenic expression of non-structural genes of Theiler's virus suppresses initial viral replication and pathogenesis of demyelination. J. Neuroinflammation 13: 133.

72. Ha S, Choi IS, Choi C, Myoung J. 2016. Infection models of human norovirus: challenges and recent progress. Arch. Virol. 161: 779-788.

73. Cho M, Myoung J. 2015. OX40 and 4-1BB downregulate Kaposi's sarcoma-associated herpesvirus replication in lymphatic endothelial cells, but 4-1BB and not OX40 inhibits viral replication in B-cells. J. Gen. Virol. 96: 3635-3645.

74. Lee JM, Kim J, Ryu I, Woo HM, Lee TG, Jung W, et al. 2017. An aptamer-based electrochemical sensor that can distinguish influenza virus subtype H1 from H5. J. Microbiol. Biotechnol. 27: 2037-2043.

75. Lee JM, Cho JB, Ahn HC, Jung W, Jeong YJ. 2017. A novel chemical compound for inhibition of SARS coronavirus helicase. J. Microbiol. Biotechnol. 27: 2070-2073.

76. Choi S, Park H, Minelko M, Kim EK, Cho MR, Nam JH. 2017. Recombinant adeno-associated virus expressing truncated IK cytokine diminishes the symptoms of inflammatory arthritis. J. Microbiol. Biotechnol. 27: 1892-1895.

77. Yoo JE, Lee C, Park S, Ko G. 2017. Evaluation of various real-time reverse transcription quantitative PCR assays for norovirus detection. J. Microbiol. Biotechnol. 27: 816-824.

78. Shin JS, Ku KB, Jang Y, Yoon YS, Shin D, Kwon OS, et al. 2017. Comparison of anti-influenza virus activity and pharmacokinetics of oseltamivir free base and oseltamivir phosphate. J. Microbiol. 55: 979-983.

79. Jeong H, Seong BL. 2017. Exploiting virus-like particles as innovative vaccines against emerging viral infections. $J$. Microbiol. 55: 220-230.

80. Kim JH, Lee CH, Lee SW. 2016. Hepatitis C virus infection stimulates transforming growth factor-beta1 expression through up-regulating miR-192. J. Microbiol. 54: 520-526.

81. Elkholy YS, Hegab AS, Ismail DK, Hassan RM. 2016. Evaluation of a novel commercial quaternary ammonium compound for eradication of Mycobacteria, HCV and HBV in Egypt. J. Microbiol. 54: 39-43.

82. Kim MJ, Lee SY, Kim HJ, Lee JS, Joo IS, Kwak HS, et al. 2016. Development of a one-step duplex RT-PCR method for the simultaneous detection of VP3/VP1 and VP1/P2B regions of the hepatitis A virus. J. Microbiol. Biotechnol. 26: 1398-1403.

83. Ahn HS, Han SH, Kim YH, Park BJ, Kim DH, Lee JB, et al. 2017. Adverse fetal outcomes in pregnant rabbits experimentally infected with rabbit hepatitis E virus. Virology 512: 187-193.

84. Lee M, Seo DJ, Seo J, Oh H, Jeon SB, Ha SD, et al. 2015. Detection of viable murine norovirus using the plaque assay and propidium-monoazide-combined real-time reverse transcription-polymerase chain reaction. J. Virol. Methods 221: 57-61. 
85. Gillen J, Li W, Liang Q, Avey D, Wu J, Wu F, et al. 2015. A survey of the interactome of Kaposi's sarcoma-associated herpesvirus ORF45 revealed its binding to viral ORF33 and cellular USP7, resulting in stabilization of ORF33 that is required for production of progeny viruses. J. Virol. 89: 4918-4931.

86. Fu B, Kuang E, Li W, Avey D, Li X, Turpin Z, et al. 2015. Activation of p90 ribosomal $\mathrm{S} 6$ kinases by ORF45 of Kaposi's sarcoma-associated herpesvirus is critical for optimal production of infectious viruses. J. Virol. 89: 195-207.

87. Lim S, Cha S, Jang JH, Yang D, Choe J, Seo T. 2016. Alterations in acetylation of histone $\mathrm{H} 4$ lysine 8 and trimethylation of lysine 20 associated with lytic gene promoters during Kaposi's sarcoma-associated herpesvirus reactivation. J. Microbiol. Biotechnol.
88. Schemmerer M, Apelt S, Trojnar E, Ulrich RG, Wenzel JJ, Johne R. 2016. Enhanced replication of hepatitis E virus strain 47832c in an A549-derived subclonal cell line. Viruses 8.

89. Devhare PB, Chatterjee SN, Arankalle VA, Lole KS. 2013. Analysis of antiviral response in human epithelial cells infected with hepatitis E virus. PLoS One 8: e63793.

90. Malmgaard L. 2004. Induction and regulation of IFNs during viral infections. J. Interferon. Cytokine Res. 24: 439-454.

91. Loo YM, Fornek J, Crochet N, Bajwa G, Perwitasari O, Martinez-Sobrido L, et al. 2008. Distinct RIG-I and MDA5 signaling by RNA viruses in innate immunity. J. Virol. 82: 335-345.

92. Takeuchi O, Akira S. 2010. Pattern recognition receptors and inflammation. Cell 140: 805-820. 